\title{
Effect of chronic exposure to ammonia on growth, food utilisation and metabolism of the European sea bass (Dicentrarchus labrax)
}

\author{
Antoine Dosdat ${ }^{\mathrm{a}, *}$, Jeanine Person-Le Ruyet ${ }^{\mathrm{b}}$, Denis Covès ${ }^{\mathrm{c}}$, Gilbert Dutto ${ }^{\mathrm{c}}$, \\ Eric Gasset ${ }^{\mathrm{c}}$, Annick Le Roux ${ }^{\mathrm{b}}$, Gilles Lemarié ${ }^{\mathrm{c}}$ \\ ${ }^{a}$ IFREMER, Direction Scientifique, 155, rue Jean-Jacques-Rousseau, 92138 Issy les Moulineaux cedex, France \\ ${ }^{b}$ IFREMER, Centre de Brest, B.P. 70, 29280 Plouzané, France \\ ${ }^{c}$ IFREMER, Station expérimentale d'Aquaculture, 34250 Palavas les Flots, France
}

Received 28 April 2003; accepted 26 August 2003

\begin{abstract}
The chronic effects of exposing sea bass (average initial weight $100 \mathrm{~g}$ ) to ammonia in water at $22{ }^{\circ} \mathrm{C}$ were first evaluated over a 61 -day period (period 1, P1) during which nine different groups were submitted to nine ambient ammonia levels ranging from 0.014 to $0.493 \mathrm{mg} \mathrm{l}^{-1}$ $\mathrm{NH}_{3}-\mathrm{N}\left(0.53-16.11 \mathrm{mg} \mathrm{l}^{-1}\right.$ total ammonia nitrogen (TA-N)) and fed using self-feeders. At the end of P1, the fish were starved for 10 days (P2). Their recovery capacity was tested over 43 days (P3) after which the exogenous ammonia supply was stopped in all treatments and the fish were allowed to feed. After 20 days of exposure a highly significant effect of ammonia was evident from the decrease in feeding activity, voluntary feed intake (VFI) and specific growth rate (SGR), and the increase in the feed conversion ratio (FCR). Ammonia exposure had no effect on circadian feeding rhythm or hourly actuation profiles. At the end of P1, the fish seemed to have adapted to all ambient ammonia concentrations tested since feeding and growth parameters were independent of ammonia levels. But they were unable to compensate for growth losses. Physiological adjustments were observed: plasma TA-N concentrations were positively related to ambient TA-N while there was no major disturbance in plasma urea. Plasma tri-iodo-thyronine concentrations were affected by ambient ammonia concentrations and there were no significant changes in hydromineral balance. During P2, oxygen consumption and urea excretion did appear to have been affected by ambient ammonia. When the exogenous supply of ammonia was stopped (P3), fish exhibited hyperphagia and compensatory growth. In fish previously exposed to the highest ammonia levels, SGR and VFI were highest, and their FCR was improved. At the end of the experiment the final average weights were similar in all of the treatments (range 337-396 g). Depending on the concentrations used, ammonia exposure may enhance subsequent fish appetite and growth rate and have a similar effect on growth performances as restricting feeding level. Within the range tested, no detrimental effect of ammonia on the metabolic capacity of the fish, measured by oxygen consumption and urea excretion, or on their physiological status was recorded, and the fish had a good recovery capacity. In the conditions of the experiment, the non-observable effect concentration (NOEC) was $6 \mathrm{mg} \mathrm{l}^{-1}$.
\end{abstract}

(C) 2003 Elsevier SAS and Ifremer/IRD/Inra/Cemagref. All rights reserved.

\section{Résumé}

Effet d'une exposition prolongée à l'ammoniaque sur la croissance, l'utilisation de la nourriture et le métabolisme du bar (Dicentrarchus labrax). Les effets d'une exposition prolongée à l'ammoniaque, sur des bars (poids moyen $140 \mathrm{~g}$ ) dans de l'eau à $22^{\circ} \mathrm{C}$, ont été évalués dans un premier temps durant une période de 61 jours (période 1, P1). Les poissons, nourris par des distributeurs « self-service », étaient alors répartis en neuf groupes soumis à neuf niveaux différents de concentration d'ammoniaque, de 0,014 à $0,493 \mathrm{mg}^{-1}$ de $\mathrm{NH}_{3}-\mathrm{N}$ $\left(0,53\right.$ à $16,11 \mathrm{mg} \mathrm{l}^{-1}$ d'azote ammoniacal total (TA-N)). À la fin de P1, les animaux ont été mis à jeun pendant dix jours (P2). Leur capacité de récupération a été ensuite testée durant 43 jours (P3) après que l'alimentation en ammoniaque eût été supprimée et que les animaux aient pu de nouveau s'alimenter. Après 20 jours d'exposition, l'activité alimentaire, les aliments ingérés volontairement (VFI) et le taux de croissance spécifique (SGR) ont diminué significativement sous l'effet de l'ammoniaque, pendant que le taux de transformation de l'aliment (FCR) a augmenté. L'exposition à l'ammoniaque n'a pas eu d'effet sur les activités circadiennes d'alimentation, ni sur les rythmes horaires de demande alimentaire. À la fin de P1, tous les poissons ont semblé s'être adaptés aux concentrations testées. En effet, les paramètres de croissance et

\footnotetext{
* Corresponding author.

E-mail address: Antoine.Dosdat@ifremer.fr (A. Dosdat).
} 
d'alimentation étaient revenus à la normale. Cependant, les poissons n'avaient pas compensé leur retard de croissance. Quelques ajustements physiologiques ont pu être observés : le taux de TA-N du plasma était positivement corrélé au taux d'ammoniaque ambiant, mais pas celui de l'urée. Le taux de tri-iodo-thyronine du plasma a été modifié, mais pas l'équilibre hydrominéral. Durant P2, la consommation d'oxygène et l'excrétion d'urée n'ont pas été affectées. Quand l'apport d'ammoniaque a pris fin (P3), les poissons ont montré de l'hyperphagie et ont manifesté une croissance compensatrice. Les poissons préalablement soumis aux plus fortes concentrations présentent les meilleurs SGR et VFI. À la fin de l'expérimentation, les poids moyens des poissons étaient comparables dans tous les traitements (entre $337 \mathrm{et} 396 \mathrm{~g}$ ). Selon sa concentration, l'ammoniaque peut entraîner une augmentation de l'appétit et du taux de croissance, ultérieurement, similaires à ceux d'un rationnement alimentaire. Dans la gamme testée, aucun effet préjudiciable de l'ammoniaque n'a été observé, ni sur les capacités métaboliques de l'animal, mesurées par sa consommation d'oxygène et l'excrétion d'urée, ni sur ses caractéristiques physiologiques. Les animaux ont montré une très bonne capacité de récupération. Dans les conditions de l'expérience, la concentration, pour laquelle aucun effet n'a pu être observé, était de $6 \mathrm{mg} \mathrm{l}^{-1}$.

(C) 2003 Elsevier SAS and Ifremer/IRD/Inra/Cemagref. All rights reserved.

Keywords: Ammonia; Chronic toxicity; Compensatory growth; Self feeding; Sea bass

\section{Introduction}

Worldwide, there is growing interest is in the control of water quality within the fish farming process in order to improve the productivity of fish production systems and to enhance fish quality and welfare. Among water quality criteria, ammonia has been described as one of the most significant limiting factors for growth and survival (Russo and Thurston, 1991; Tomasso, 1994). This constraint has been re-enforced by the recent developments in water recirculation technologies and systems in marine and freshwater fish farming (Blancheton, personal communication), and by the issues concerning environmental impacts attributable to nitrogen loading (Handy and Poxton, 1993; Dosdat et al., 1996). Ammonia and urea are the two major end-products of nitrogen metabolism in fish (Forster and Goldstein, 1969). Mainly excreted through the gills, ammonia production by fish is primarily dependant on protein intake, and on the metabolic efficiency of the fish, which is species specific and is affected by increasing levels of ambient ammonia. Both the ionised $\left(\mathrm{NH}_{4}^{+}\right)$and unionised $\left(\mathrm{NH}_{3}\right.$, UIA-N) forms of total ammonia nitrogen (TA-N) are toxic to fish, but the unionised form seems to be much more toxic. The equilibrium between the two forms is highly dependent on $\mathrm{pH}$, salinity and temperature (Handy and Poxton, 1993).

While acute toxicity tests are well documented, data concerning chronic ammonia toxicity to marine fish are relatively scarce, partly because of the technical difficulty in maintaining steady-state environmental parameters over a long period (US EPA, 1998). Acute and chronic ammonia toxicity (1-3 months of exposure) has been reported on turbot juveniles (Rasmussen and Korsgaard, 1996; Person-Le Ruyet et al., 1997a, b; Person-Le Ruyet et al., 1998) and sea bream juveniles (Wajsbrot et al., 1993; Person-Le Ruyet et al., 1995). In sea bass juveniles, the 96-h $\mathrm{LC}_{50}$ was $40 \mathrm{mg} \mathrm{l}^{-1}$ TA-N (1.7 $\mathrm{mg} \mathrm{l}^{-1}$ UIA-N) (Person-Le Ruyet et al., 1995) and the 55-day $\mathrm{EC}_{50}$ (concentration at which growth is reduced by $50 \%$ after 55 days) was $22 \mathrm{mg} \mathrm{l}^{-1}$ TA-N (0.9 $\mathrm{mg} \mathrm{l}^{-1}$ UIA-N) (Lemarié et al., in press). The main purpose of the present experiment was to evaluate the effects of chronic low ammonia concentrations (i.e. usual concentra- tions in sea bass farming) on market size fish in terms of growth rate, food utilisation, metabolism and physiological status. The sea bass recovery capacity when exogenous ammonia supply was stopped was also studied.

\section{Materials and methods}

\subsection{Fish and rearing conditions}

Immature sea bass were reared at the IFREMER Station in Palavas from eggs to day 140 (average weight $8 \mathrm{~g}$ ) in semiclosed systems (Lemarié et al., in press), and then raised in flow-through systems up to an average weight of $100 \mathrm{~g}$ (average temperature $18.0 \pm 2.5^{\circ} \mathrm{C}$ ) for 11 months. The fish were then graded and those within the weight range $(100.0 \pm 16.5 \mathrm{~g})$ were randomly distributed (110 fish per tank) in nine circular tanks (effective volume $1 \mathrm{~m}^{3}$ ) in a sound proof facility. Forty of the 110 fish were sampled at random and were individually tagged using PIT-tags (Fish Eagle®). The fish were then acclimated to the rearing conditions for 40 days prior to the experiment. The fish were fed expanded pellets (45\% protein, $21.5 \%$ crude fat, digestible energy of $18.9 \mathrm{~kJ} \mathrm{~g}^{-1}$ dry matter), using an on-demand system based upon the one described by Boujard et al. (1992). When the fish touched a rod located below the surface of the water, an electric pulse was generated, which actuated an electric feeder that released a predetermined amount of feed (1.7$1.9 \mathrm{~g}$ ). This rod was protected by a cylindrical screen in order to avoid unintentional fish contacts and limit food wastage. Every day, the feeding system was turned off between 9:00 and 10:00 $\mathrm{h}$ in order to replenish the feeders and to check for the presence of uneaten pellets collected in a sedimentation trap located at the outlet of each tank.

The tanks were filled by gravity with running sea water, which had been sand-filtered at $15 \mu \mathrm{m}$, UV sterilised, heated, and degassed in a packed column. The flow rate was set at $1 \mathrm{~m}^{3} \mathrm{~h}^{-1}$ (accuracy of the flow-meter: $\pm 0.05 \mathrm{~m}^{3} \mathrm{~h}^{-1}$ ) in order to permanently maintain an oxygen saturation of above $80 \%$ in the outflow water and to provide self-cleaning of the tank. The temperature was maintained at $22.0{ }^{\circ} \mathrm{C}$ using a heat- 
exchanger and checked hourly. Salinity and $\mathrm{pH}$ were checked once a day. Light intensity at the water surface was $250 \mathrm{~lx}$, and the photoperiod was maintained at $16 \mathrm{~h}$ light- $8 \mathrm{~h}$ dark, including a $30 \mathrm{~min}$ artificial dawn and dusk, using an incandescent lamp (OSRAM Decor Silver E27).

\subsection{Experimental design}

The experiment was divided into three periods. During period 1, which lasted 61 days, fish were fed and exposed to ambient ammonia to evaluate its effect on fish growth, feeding and physiology. During period 2, which lasted 10 days, the fish were starved and submitted to ambient ammonia to evaluate the standard metabolism. Finally, during period 3, which lasted 43 days, the fish were no longer exposed to ammonia and were fed again to investigate their recovery capacity.

Eight different concentrated ammonia chloride solutions were fed into the water inlet from day 1 to 71 (period 1 and 2) using a peristaltic pump (eight channels, flow rate $5 \mathrm{ml}$ $\mathrm{min}^{-1}$ ). These concentrated solutions were obtained by dissolving 24-123 $\mathrm{g} \mathrm{l}^{-1}$ of ammonium chloride powder $\left(\mathrm{NH}_{4} \mathrm{Cl}\right.$, BASF®, $99.5 \%$ pure) in tap water in order to obtain eight ambient TA-N concentrations (T1-T8) ranging from 4 to $16 \mathrm{mg} \mathrm{l}^{-1}$ TA-N. This concentration range represented $10-40 \%$ of the $96-\mathrm{h} \mathrm{LC}_{50}$ as reported by Person-Le Ruyet et al. (1995). No ammonia solution was added to the control tank. The ambient ammonia concentration within each tank was checked daily in a $24 \mathrm{~h}$-pooled sample of water, obtained from the effluent water and poured into a 21 bottle where $5 \mathrm{ml}$ of $99.5 \%$ chloroform were first added for the purpose of stabilisation (Dosdat et al., 1994). The TA-N concentration was then determined by the indophenol method (Bower and Holm-Hansen, 1980), using a Technicon Analyser®. The pH was measured daily at the outlet of every tank using a Tacussel PHN81® pH-meter, coupled with a Tacussel TC100® probe containing a saturated solution of $\mathrm{KCl} / \mathrm{AgCl}$ (Tacussel $\mathrm{KS} 120 \AA$ ) and an $\mathrm{Ag} / \mathrm{AgCl}$ reference electrode (Johansson and Wedborg, 1980). UIA-N concentrations were calculated from TA-N according to $\mathrm{pH}$, temperature and salinity, using the equation of Johansson and Wedborg (1980). Therefore, the percentage of UIA-N to TA-N was given by the following equation:

$\% \mathrm{NH}_{3}=\frac{100}{1+10^{\left(\log K_{1}-\mathrm{pH}\right)}}$

with $\log K_{1}=-0.467+0.00113 \times S+2.887 .9 \times T^{-1}$, where $K_{1}$ is the dissociation constant, $S$ (in $\mathrm{g}^{-1}$ ) the salinity and $T$ the temperature $\left({ }^{\circ} \mathrm{K}\right)$.

On day 1, 19, 41, 61 (period 1), 71 (period 2), 93 and 114 (period 3), the fish, which had fasted for $24 \mathrm{~h}$, were anaesthetised (using a solution containing $150 \mathrm{mg} \mathrm{l}^{-1}$ of ethyleneglycol-monophenyl-ether) and counted. The 40 tagged fish were individually weighed to the nearest $0.01 \mathrm{~g}$. In order to avoid a decrease in the oxygen concentration due to increasing biomass, stocking density was reduced on day 20 by removing at random 20 untagged fish per tank. Mortality was monitored daily. On day 61, 25 fish were removed for sampling.

\subsection{Parameters studied}

The mean wet weights \pm S.D. were calculated as the arithmetic mean from the samples of the same 40 tagged fish. At the end of every phase, the specific growth rate (SGR) was determined as:

$\mathrm{SGR}=\frac{\left(\operatorname{Ln} W_{\mathrm{f}}-\operatorname{Ln} W_{\mathrm{i}}\right) \times 100}{\mathrm{~T}}$

where $W_{\mathrm{f}}$ is the mean wet weight in grams $(n=40)$ at the end of the phase, $W_{\mathrm{i}}$ is the initial mean wet weight $(n=40)$ and $T$ the duration of the phase in days.

Variation in fish size within the tank were described by means of a comparison of coefficients of variation $(\mathrm{CV})$ using the following equation:

$\mathrm{CV}=\frac{100 \times \mathrm{SD} \text { of the individual weight }}{\text { mean weight }}$

The daily voluntary feed intake (VFI, \% of fish biomass) during each phase was calculated as follows:

$\mathrm{VFI}=\frac{2 \times\left[\text { Ingested feed } /\left(\left(\mathrm{W}_{\mathrm{f}}+\mathrm{W}_{\mathrm{i}}\right) \times \text { fish number }\right)\right]}{\mathrm{T}}$

where the ingested feed is the feed delivered during the phase minus the feed collected in the traps.

For each phase, the feed conversion ratio (FCR) was calculated as:

$\mathrm{FCR}=\frac{\text { Ingested feed }}{\left[\left(W_{\mathrm{f}}-W_{\mathrm{i}}\right) \times \text { fish number }\right]}$

Apparent digestibility coefficient for proteins (ADC) was measured at the end of period 1 over three consecutive days in each tank using settlement collectors attached to the tanks (Lemarié et al., in press). Chromic oxide $\left(\mathrm{Cr}_{2} \mathrm{O}_{3} ; 1 \%\right.$ of the feed) was utilised as a marker. Analyses on feed and fish were performed using usual standardised methods, i.e. dry matter after drying for $24 \mathrm{~h}$ at $105^{\circ} \mathrm{C}$, crude proteins by the Dumas method (using a Fison ${ }^{\circledR}$ NA 2000 analyser) and crude lipid by dichloromethane extraction with an automatic Soxlet ${ }^{\circledR}$ apparatus. Chromic oxide content in the faeces and in the feed was estimated using the method described by Bolin et al. (1952). The ADC were calculated using the standard formulae:

$$
\begin{aligned}
& \operatorname{ADC}(\%)=100 \\
& -\left[100\left(\frac{\% \mathrm{Cr} \text { in the diet }}{\% \mathrm{Cr} \text { in the faeces }}\right) \times\left(\frac{\% \mathrm{~N} \text { in the faeces }}{\% \mathrm{~N} \text { in the diet }}\right)\right]
\end{aligned}
$$

where $\mathrm{Cr}$ is the inert $\mathrm{Cr}_{2} \mathrm{O}_{3}$ marker and $\mathrm{N}$ the nitrogen.

The protein productive value (PPV) was estimated as the ratio between the protein gain and the crude protein intake.

Oxygen consumption was determined for six experimental conditions (control, T1, T3, T4, T6 and T7) during period 
2 on sea bass starved for 6-11 days. Oxygen concentrations of inlet and outlet water from each tank were monitored every $40 \mathrm{~min}$ for five consecutive days, from day 67 to 71 , using the methodology described in Lemarié et al. (in press). Part of the inflow and outflow water was diverted through solenoid valves to a measure chamber where oxygen concentration was measured using a Ysi $58 \AA$ oxymeter. Oxygen data were recorded on a data logger (Grant-Squirrel model SQ16-4V-1D). The same method was utilised to control oxygen levels during the whole experiment. Oxygen consumption $\left(\mathrm{MO}_{2}\right)$ was calculated as follows:

$$
\begin{aligned}
\mathrm{MO}_{2}\left(\mathrm{mg} \mathrm{kg}^{-1} \mathrm{~h}^{-1}\right) & =\left(\left[\mathrm{O}_{2}\right] \text { inlet }-\left[\mathrm{O}_{2}\right] \text { outlet }\right) \\
& \times \text { flow rate }\left(\mathrm{m}^{3} \mathrm{~h}^{-1}\right) \times \text { fish biomass } \\
-1 & \left(\mathrm{~kg} \mathrm{~m}^{-3}\right)
\end{aligned}
$$

Urea production was monitored using the method described by Dosdat et al. (1994). Inflow and outflow water was collected using a peristaltic pump and bulked into 11 polypropylene bottles, where the samples were stabilised using chloroform. Urea was analysed using a Technicon ${ }^{\circledR}$ Autoanalyser II by the acetyl-monoxyme method (Aminot and Kérouel, 1982) within $48 \mathrm{~h}$ of sampling.

On day 61, blood samples were collected from vessels at the caudal peduncle of eight fish fasted for $24 \mathrm{~h}$ per experimental condition tested (control, T1, T3, T5, T6 and T8). The blood was immediately centrifuged and plasma TA-N content determined within $1 \mathrm{~h}$ using the enzymatic kit Sigma Diagnostic UV-170®. All other analyses were performed on plasma samples that had been stored at $-20{ }^{\circ} \mathrm{C}$ : osmolarity (Advanced microosmometer ${ }^{\circledR}$ ), chloride (Chloridometer Radiometer ${ }^{\circledR}$ ), sodium and potassium concentrations (Electrolyte Beckman Analyser®), urea content using the Sigma Diagnostic 535® kit and plasma glucose using the Sigma Diagnostic 16-UV® kit. A radio-immunoassay was used to measure plasma tri-iodo-thyronine, $\mathrm{T}_{3}$ (Bœuf et al., 1989).

\subsection{Statistical analysis}

Where needed, experimental data were processed by a one-way analysis of variance (ANOVA), and when necessary by an analysis of co-variance (ANCOVA). A two-way ANOVA was used to discriminate VFI and FCR. Differences among the means were determined by a Student-NewmanKeuls (SNK) test that was applied to ranks when normality was not established. Linear regressions (LR) were performed to analyse correlations between factors. The comparisons between $\mathrm{CV}$ were performed by means of a sign-test. The Statistica (Statsoft) package was used to process the data.

\section{Results}

\subsection{Environmental conditions}

The environmental conditions were stable: the temperature at $22.0 \pm 0.2^{\circ} \mathrm{C}($ mean \pm S.D.,$n=114)$ and the salinity at $37.0 \pm 2.5 \mathrm{~g} \mathrm{l}^{-1}(n=114)$. Oxygen never fell below $76 \%$ of saturation. The stability of the different ambient TA-N concentrations was acceptable, the $\mathrm{CV}$ ranging from 11 to $17 \%$ (Table 1). Mean ambient $\mathrm{pH}$ varied by less than 0.06 in all treatments (7.80 in the control group compared to 7.86 in the T8 group); as a result, the UIA-N fraction relative to TA-N was similar (average 2.8\%; range 2.7-3.0 under all experimental conditions).

\subsection{Period 1 (ambient ammonia, fed fish)}

No mortality was observed during the whole period. Growth was observed in all conditions (Fig. 1). The significance of the Fisher test applied to weight increased from 1.8 to 10.9 with time, indicating that the intertreatment variance increased faster than the residual variance (intragroup). The CV of fish weight between treatments at day 1 were not significantly different from day 19 ( ign-test, $n=9, P>0.05$ ). They decreased from day 19 to $41(P=0.038)$ and were maintained at that level from day 41 to 61 . At day 19 , the lowest weights were observed in fish exposed to ammonia levels exceeding $10.22 \mathrm{mg} \mathrm{l}^{-1}$ TA-N. At the end of period 1 (day 61), the fish exposed to the three highest TA-N levels were the smallest, and the largest were observed in the control tank and under the 3.10 and $6.16 \mathrm{mg} \mathrm{l}^{-1}$ TA-N conditions.

After a significant decrease of the SGR, which was related to the level of ammonia during the first 19 days in all treat-

Table 1

\begin{tabular}{|c|c|c|c|c|c|}
\hline \multirow[t]{2}{*}{ Tank } & \multirow[t]{2}{*}{$n$} & \multicolumn{2}{|c|}{ Measured TA-N $\left(\mathrm{mg} \mathrm{l}^{-1}\right)$} & \multirow{2}{*}{$\begin{array}{l}\text { Calculated UIA-N }\left(\mathrm{mg} \mathrm{l}^{-1}\right) \\
\text { Mean } \pm \text { S.D. }\end{array}$} & \multirow{2}{*}{$\begin{array}{l}\text { Measured } \mathrm{pH} \\
\text { Mean } \pm \text { S.D. }\end{array}$} \\
\hline & & Mean \pm S.D. & $\mathrm{CV}(\%)$ & & \\
\hline Control & 61 & $0.53 \pm 0.13^{\mathrm{a}}$ & 22.2 & $0.014 \pm 0.001$ & $7.80 \pm 0.03$ \\
\hline $\mathrm{T} 1$ & 61 & $3.10 \pm 0.42^{\mathrm{b}}$ & 13.8 & $0.085 \pm 0.003$ & $7.81 \pm 0.02$ \\
\hline $\mathrm{T} 2$ & 61 & $4.90 \pm 0.70^{\mathrm{c}}$ & 14.3 & $0.134 \pm 0.005$ & $7.81 \pm 0.05$ \\
\hline $\mathrm{T} 3$ & 61 & $6.16 \pm 0.98^{\mathrm{d}}$ & 15.8 & $0.169 \pm 0.006$ & $7.81 \pm 0.03$ \\
\hline $\mathrm{T} 4$ & 61 & $8.53 \pm 1.18^{e}$ & 13.9 & $0.250 \pm 0.007$ & $7.84 \pm 0.02$ \\
\hline T5 & 61 & $10.22 \pm 1.12^{\mathrm{f}}$ & 11.0 & $0.299 \pm 0.008$ & $7.84 \pm 0.03$ \\
\hline T6 & 61 & $10.79 \pm 1.38^{\mathrm{g}}$ & 12.8 & $0.323 \pm 0.008$ & $7.85 \pm 0.03$ \\
\hline $\mathrm{T} 7$ & 61 & $14.45 \pm 1.84^{\mathrm{h}}$ & 12.7 & $0.433 \pm 0.012$ & $7.85 \pm 0.04$ \\
\hline $\mathrm{T} 8$ & 61 & $16.11 \pm 2.80^{\mathrm{i}}$ & 17.4 & $0.493 \pm 0.015$ & $7.86 \pm 0.03$ \\
\hline
\end{tabular}

TA-N and UIA-N concentrations (mean \pm S.D., $\left.\mathrm{mg} \mathrm{l}^{-1}\right)$ in seawater $\left(37.0 \pm 2.5 \mathrm{~g}^{-1}\right)$ during period $1 . F(540,8)=840$ for the one-way ANOVA

Letters following means indicate intergroup statistical differences between ambient TA-N concentrations. Means in the same column not sharing a common superscript were significantly different $(P<0.05)$. 


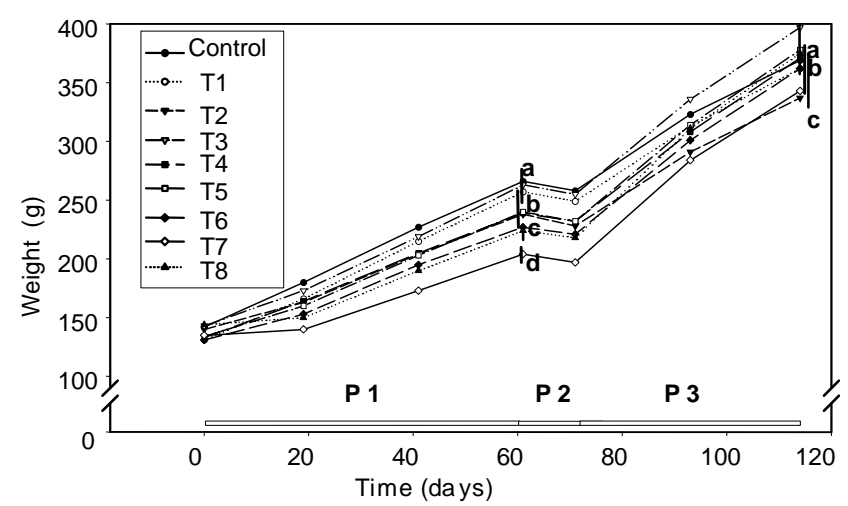

Fig. 1. Growth of sea bass exposed to various ambient ammonia levels and consecutive growth after ammonia removal. Letter on vertical bars indicates treatments not significantly different. Data are mean \pm S.E. $(n=40)$. Letters following means indicate intergroup statistical differences between ambient TA-N concentrations. Means in the same row not sharing a common superscript were significantly different $(P<0.05)$; NS, no significant differences.

ments except T1, acclimated fish exhibited growth rates comparable to the control (Table 2). These results were mainly correlated to ammonia levels since introducing individual weight as a co-variable did not modify the significance of the ANOVA. Over the 61-day experiment, the biomass increased by 1.9 in the control and only by 1.6 with the highest ammonia concentrations tested. For the whole period (day 1-61) three groups were identified: below 6.16, above $10.79 \mathrm{mg} \mathrm{l}^{-1}$ TA-N, and an intermediate group. Tank T2 $(\mathrm{SGR}=0.87)$, which had abnormal growth in weight throughout the experiment for reasons that are not clear, may be considered a special case.

Feeding activity was recorded by counting the number of times the feeding mechanism had been actuated. No actuation occurred during the night and no effect of ambient ammonia concentration was noticed on hourly actuation profiles. Typical actuation profiles in the two extreme conditions are given in Fig. 2. A comparison between fish acclimated to ammonia (day 51-61) and fish acclimated to ammonia free conditions (day 104-114), using the $\chi^{2}$ test on the average hourly number of actuations, failed to demonstrate any effect of ammonia level on actuation profiles $(\alpha=0.05)$.

In contrast, the daily number of actuations was affected on un-acclimated fish. Throughout the first period, feeding activity was highly variable from day to day but no feed wastage was observed. From day 1 to 19, a two-way ANOVA on tanks and days (16 sets of data available) showed that the daily number of actuations was significantly different among the tanks $(F(120,8)=13.6, n=9)$ and on different days $(F(120,15)=4.0, n=16)$. A SNK test on rank revealed three groups: the fish from the control and T1 conditions (respectively, 124 and 116 actuations per day), the T8 and T9 conditions (respectively, 37 and 43 actuations per day) and an intermediate group. This distribution progressively disappeared and was insignificant during the day 51-61 phase $(F(72,8)=1.6, n=9)$.

Table 2

Periods 1 and 3: initial weights (g, mean \pm S.D., $n=40)$ and specific growth weight (\% per day) of sea bass (mean \pm S.D., $n=40)$ vs. ambient ammonia at the end of each phase

\begin{tabular}{|c|c|c|c|c|c|c|}
\hline \multirow[t]{2}{*}{ Tank } & \multicolumn{2}{|l|}{ Weight } & \multicolumn{4}{|l|}{ SGR } \\
\hline & TA-N $\left(\mathrm{mg} \mathrm{l}^{-1}\right)$ & Day 1 & Day $1-19$ & Day 19-41 & Day 41-61 & Day 1-61 \\
\hline \multicolumn{7}{|l|}{ Period 1} \\
\hline Control & 0.53 & $142.2 \pm 24.9$ & $1.23 \pm 0.18^{\mathrm{a}}$ & $1.05 \pm 0.12^{\mathrm{b}, \mathrm{c}}$ & $0.79 \pm 0.12^{\mathrm{b}, \mathrm{c}}$ & $1.02 \pm 0.09^{\mathrm{a}}$ \\
\hline $\mathrm{T} 1$ & 3.10 & $131.5 \pm 21.2$ & $1.22 \pm 0.14^{\mathrm{a}}$ & $1.19 \pm 0.16^{\mathrm{a}}$ & $0.84 \pm 0.12^{b}$ & $1.08 \pm 0.11^{\mathrm{a}}$ \\
\hline $\mathrm{T} 2$ & 4.90 & $139.9 \pm 21.5$ & $0.82 \pm 0.23^{\mathrm{d}}$ & $1.02 \pm 0.17^{\mathrm{c}, \mathrm{d}}$ & $0.77 \pm 0.13^{c}$ & $0.87 \pm 0.11^{\mathrm{c}}$ \\
\hline $\mathrm{T} 3$ & 6.16 & $142.7 \pm 18.8$ & $1.02 \pm 0.17^{\mathrm{c}}$ & $1.06 \pm 0.11^{\mathrm{b}, \mathrm{c}}$ & $0.92 \pm 0.11^{\mathrm{a}}$ & $1.00 \pm 0.09^{\mathrm{a}, \mathrm{b}}$ \\
\hline $\mathrm{T} 4$ & 8.53 & $132.6 \pm 21.2$ & $1.10 \pm 0.17^{\mathrm{b}}$ & $1.03 \pm 0.14^{\mathrm{b}, \mathrm{c}, \mathrm{d}}$ & $0.75 \pm 0.15^{\mathrm{c}}$ & $0.96 \pm 0.12^{b}$ \\
\hline T5 & 10.22 & $134.5 \pm 21.1$ & $0.88 \pm 0.18^{\mathrm{d}}$ & $1.09 \pm 0.14^{\mathrm{b}, \mathrm{c}}$ & $0.84 \pm 0.13^{b}$ & $0.94 \pm 0.09^{b}$ \\
\hline T6 & 10.79 & $131.3 \pm 24.1$ & $0.81 \pm 0.12^{\mathrm{d}}$ & $1.12 \pm 0.15^{\mathrm{a}, \mathrm{b}}$ & $0.75 \pm 0.12^{\mathrm{c}}$ & $0.90 \pm 0.10^{\mathrm{b}, \mathrm{c}}$ \\
\hline $\mathrm{T} 7$ & 14.45 & $134.5 \pm 21.2$ & $0.21 \pm 0.17^{\mathrm{e}}$ & $0.96 \pm 0.24^{\mathrm{d}}$ & $0.84 \pm 0.14^{b}$ & $0.69 \pm 0.13^{\mathrm{d}}$ \\
\hline T8 & 16.11 & $143.9 \pm 21.1$ & $0.21 \pm 0.15^{\mathrm{e}}$ & $1.05 \pm 0.13^{\mathrm{b}, \mathrm{c}}$ & $0.85 \pm 0.10^{b}$ & $0.72 \pm 0.09^{\mathrm{d}}$ \\
\hline$F(350,8)$ & & 1.8 & 205.9 & 6.9 & 8.4 & 63.8 \\
\hline Tank & TA-N (mg l'-1) & Day 71 & Day 71-93 & Day $93-114$ & Day 71-114 & \\
\hline Control & 0.53 & $258.2 \pm 41.3^{\mathrm{a}}$ & $1.01 \pm 0.14^{\mathrm{e}}$ & $0.62 \pm 0.18^{b}$ & $0.82 \pm 0.13^{\mathrm{e}}$ & \\
\hline $\mathrm{T} 1$ & 3.10 & $249.2 \pm 40.5^{\mathrm{a}, \mathrm{b}}$ & $1.04 \pm 0.31^{\mathrm{d}, \mathrm{e}}$ & $0.69 \pm 0.16^{b}$ & $0.87 \pm 0.20^{\mathrm{d}, \mathrm{e}}$ & \\
\hline $\mathrm{T} 2$ & 4.90 & $228.0 \pm 33.3^{c}$ & $1.11 \pm 0.22^{\mathrm{d}}$ & $0.69 \pm 0.15^{b}$ & $0.90 \pm 0.16^{\mathrm{d}}$ & \\
\hline $\mathrm{T} 3$ & 6.16 & $255.0 \pm 30.5^{\mathrm{a}}$ & $1.25 \pm 0.14^{\mathrm{c}}$ & $0.79 \pm 0.14^{\mathrm{a}}$ & $1.02 \pm 0.13^{\mathrm{c}}$ & \\
\hline $\mathrm{T} 4$ & 8.53 & $232.0 \pm 41.6^{\mathrm{b}, \mathrm{c}}$ & $1.29 \pm 0.27^{\mathrm{b}, \mathrm{c}}$ & $0.88 \pm 0.31^{\mathrm{a}}$ & $1.09 \pm 0.11^{\mathrm{b}}$ & \\
\hline $\mathrm{T} 5$ & 10.22 & $232.3 \pm 36.6^{\mathrm{b}, \mathrm{c}}$ & $1.38 \pm 0.18^{b}$ & $0.89 \pm 0.14^{\mathrm{a}}$ & $1.14 \pm 0.14^{\mathrm{b}}$ & \\
\hline T6 & 10.79 & $221.1 \pm 35.7^{\mathrm{c}}$ & $1.39 \pm 0.19^{b}$ & $0.89 \pm 0.12^{\mathrm{a}}$ & $1.14 \pm 0.11^{\mathrm{b}}$ & \\
\hline $\mathrm{T} 7$ & 14.45 & $196.7 \pm 29.2^{\mathrm{d}}$ & $1.68 \pm 0.21^{\mathrm{a}}$ & $0.89 \pm 0.13^{\mathrm{a}}$ & $1.29 \pm 0.15^{\mathrm{a}}$ & \\
\hline T8 & 16.11 & $218.0 \pm 41.1^{\mathrm{c}}$ & $1.62 \pm 0.14^{\mathrm{a}}$ & $0.88 \pm 0.14^{\mathrm{a}}$ & $1.26 \pm 0.12^{\mathrm{a}}$ & \\
\hline$F(429,10)$ & & 11.3 & 52.0 & 15.3 & 55.4 & \\
\hline
\end{tabular}

Letters following means indicate intergroup statistical differences between ambient TA-N concentrations. Means in the same column not sharing a common superscript were significantly different $(P<0.05)$. 
Table 3

Weight losses, urea excretion and oxygen consumption (mean \pm S.D., $n=40$ ) in fasting fish during period 2

\begin{tabular}{|c|c|c|c|c|c|c|c|c|c|}
\hline & Tank & & & & & & & & \\
\hline & Control & $\mathrm{T} 1$ & $\mathrm{~T} 2$ & $\mathrm{~T} 3$ & $\mathrm{~T} 4$ & $\mathrm{~T} 5$ & T6 & $\mathrm{T} 7$ & $\mathrm{~T} 8$ \\
\hline $\begin{array}{l}\text { Percentage of weight } \\
\text { loss }\end{array}$ & 3.0 & 2.9 & 4.0 & 2.9 & 2.9 & 3.2 & 2.5 & 3.7 & 2.9 \\
\hline SGR & $-0.05 \pm 0.01^{\mathrm{a}, \mathrm{b}}$ & $-0.05 \pm 0.01^{\mathrm{a}, \mathrm{b}}$ & $-0.07 \pm 0.02^{\mathrm{d}}$ & $-0.05 \pm 0.01^{\mathrm{a}, \mathrm{b}}$ & $-0.05 \pm 0.01^{\mathrm{a}, \mathrm{b}}$ & $-0.05 \pm 0.01^{\mathrm{b}}$ & $-0.04 \pm 0.01^{\mathrm{a}}$ & $-0.06 \pm 0.02^{\mathrm{c}}$ & $-0.05 \pm 0.02^{\mathrm{a}, \mathrm{b}}$ \\
\hline $\begin{array}{l}\text { Urea excretion } \\
\left(\mathrm{mg} \mathrm{kg}^{-1} \mathrm{BW} \mathrm{d} \mathrm{d}^{-1}\right)\end{array}$ & $20.6 \pm 2.2$ & $23.5 \pm 2.9$ & $24.8 \pm 3.5$ & $22.8 \pm 1.3$ & $26.4 \pm 1.9$ & $27.3 \pm 5.7$ & $27.3 \pm 3.8$ & $28.0 \pm 6.3$ & $28.5 \pm 2.1$ \\
\hline $\begin{array}{l}\mathrm{O}_{2} \text { consumption } \\
\left(\mathrm{mg} \mathrm{kg}^{-1} \mathrm{BW} \mathrm{h} \mathrm{h}^{-1}\right)\end{array}$ & $155.3 \pm 7.9$ & $171.1 \pm 6.4$ & - & $167.9 \pm 5.4$ & $160.4 \pm 4.7$ & - & $152.2 \pm 7.1$ & $149.2 \pm 12.4$ & - \\
\hline
\end{tabular}

Letters following means indicate intergroup statistical differences between ambient TA-N concentrations. Means in the same row not sharing a common superscript were significantly different $(P<0.05)$.
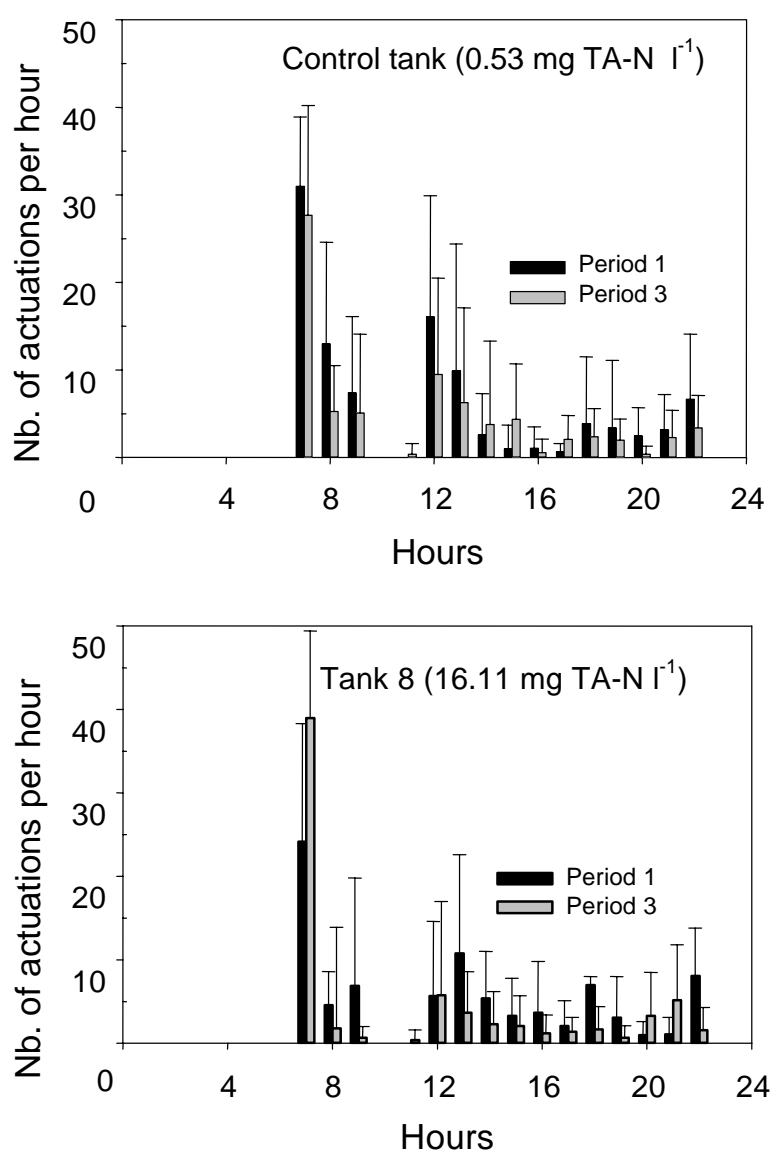

Fig. 2. Hourly actuation profiles in two tanks, which differ in the ambient ammonia level during period 1 . Vertical bars represent the mean of last 10 consecutive days of period 1 and 3. S.D. is given above. The horizontal bar represents the light period.

Overall, 20-40\% of the actuations occurred during the first hour of the photophase. A one-way ANOVA on the number of actuations during the first hour of light was only significant during the day $1-19$ phase $(F(135,8)=16.2$, $n=9)$, suggesting that ammonia levels had no effect on the initial feeding activity of fish acclimated for more than 19 days.

VFI was also dependent on ammonia concentration (Table 4). Initial exposure to $10.79,14.45$ and $16.11 \mathrm{mg} \mathrm{l}^{-1}$ TA-N induced 3, 9 and 10 days, respectively, of voluntary starvation, followed by a recovery of the appetite. From day
1 to 19 , the regression between ammonia level and the average VFI (in \% per day) was the following:

$$
\mathrm{VFI}=-0.07 \times \mathrm{TA}-\mathrm{N}+1.72 ; \quad \mathrm{r}^{2}=0.91, \mathrm{n}=171
$$

The slope was significantly different from zero. This relation was not significant for the day 19-41 and 41-61 phases. Nevertheless, from day 19 to 41 VFI tended to increase in fish exposed to ammonia levels above $8.53 \mathrm{mg} \mathrm{l}^{-1} \mathrm{TA}-\mathrm{N}$, and decreased in the other treatments. During the whole period (day 1-61), a very strong correlation was obtained between SGR and VFI $\left(r=0.92, P=3 \times 10^{-14}\right)$.

The FCR was affected by ammonia levels during the day $1-19$ phase (Table 4) and in the 14.45 and $16.11 \mathrm{mg} \mathrm{l}^{-1}$ TA-N groups. For the whole period (day 1-61), the FCR was not significantly different among treatments, averaging 1.4. Fig. 3 indicates the trends of ADC, PPV, and fish lipid content at the end of the period according to the level of ammonia. No particular significant relationship could be detected between these parameters and ambient ammonia levels.

In sea bass acclimated to ammonia for 61 days, no major disturbances in hydromineral balance and no signs of stress or anaemia were observed (Table 5). Plasma ammonia was dependent on ambient ammonia. The relationship between plasma $(y)$ and ambient $(x)$ TA-N $\left(\mathrm{mg} \mathrm{l}^{-1}\right)$ is expressed by the following equation:

$$
\mathrm{y}=0.52 \mathrm{x}+3.21 ; \quad \mathrm{r}^{2}=0.97, \mathrm{n}=35
$$

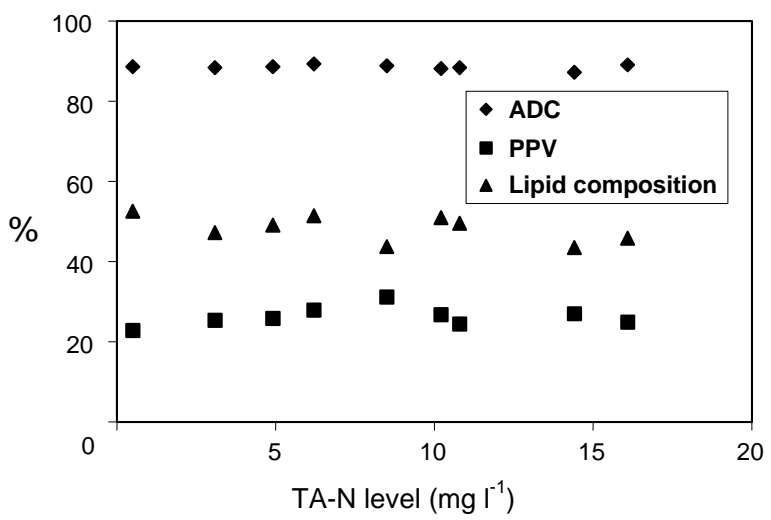

Fig. 3. ADC, PPV and lipid composition of fish exposed to various ammonia levels from day 1 to 61 . 
Table 4

VFI (\% of fish biomass) and FCR of sea bass exposed to various TA-N levels in seawater during period 1 and 3

\begin{tabular}{|c|c|c|c|c|c|c|c|c|c|c|c|c|c|c|}
\hline & \multicolumn{7}{|l|}{ VFI } & \multicolumn{7}{|l|}{ FCR } \\
\hline & \multicolumn{4}{|l|}{ Period 1} & \multicolumn{3}{|c|}{ Period 3} & \multicolumn{4}{|c|}{ Period 1} & \multicolumn{3}{|c|}{ Period 3} \\
\hline & Day & Day & Day & Mean & Day & Day & Mean & Day & Day & Day & Mean & Day & Day & Mean \\
\hline & 0-19 & $19-41$ & $41-61$ & & 71-93 & $93-114$ & & $0-19$ & $19-41$ & $41-61$ & & $71-93$ & $93-114$ & \\
\hline \multicolumn{15}{|l|}{ Tank } \\
\hline Control & 1.58 & 1.30 & 1.06 & $1.34^{\mathrm{a}}$ & 1.33 & 1.07 & $1.20^{\mathrm{b}}$ & 1.29 & 1.27 & 1.41 & 1.32 & 1.45 & 1.72 & $1.59^{\mathrm{a}}$ \\
\hline $\mathrm{T} 1$ & 1.58 & 1.47 & 1.15 & $1.40^{\mathrm{a}}$ & 1.45 & 1.11 & $1.28^{\mathrm{b}}$ & 1.31 & 1.19 & 1.45 & 1.32 & 1.41 & 1.59 & $1.50^{\mathrm{a}}$ \\
\hline $\mathrm{T} 2$ & 1.27 & 1.30 & 1.08 & $1.22^{\mathrm{a}}$ & 1.76 & 1.19 & $1.48^{\mathrm{a}}$ & 1.25 & 1.23 & 1.48 & 1.32 & 1.56 & 1.72 & $1.64^{\mathrm{a}}$ \\
\hline T3 & 1.28 & 1.24 & 1.06 & $1.19^{\mathrm{a}}$ & 1.71 & 1.19 & $1.45^{\mathrm{a}}$ & 1.26 & 1.12 & 1.22 & 1.20 & 1.38 & 1.50 & $1.44^{\mathrm{a}}$ \\
\hline $\mathrm{T} 4$ & 1.23 & 1.23 & 1.00 & $1.15^{\mathrm{a}}$ & 1.63 & 1.25 & $1.44^{\mathrm{a}}$ & 1.12 & 1.14 & 1.39 & 1.22 & 1.26 & 1.41 & $1.34^{\mathrm{a}, \mathrm{b}}$ \\
\hline T5 & 1.04 & 1.27 & 1.03 & $1.11^{\mathrm{a}}$ & 2.01 & 1.31 & $1.66^{\mathrm{a}}$ & 1.15 & 1.12 & 1.29 & 1.19 & 1.47 & 1.48 & $1.48^{\mathrm{a}}$ \\
\hline T6 & 1.01 & 1.26 & 1.01 & $1.09^{\mathrm{a}}$ & 1.78 & 1.29 & $1.54^{\mathrm{a}}$ & 1.27 & 1.08 & 1.42 & 1.26 & 1.28 & 1.47 & $1.38^{\mathrm{a}}$ \\
\hline $\mathrm{T} 7$ & 0.52 & 1.10 & 0.94 & $0.82^{b}$ & 2.01 & 1.37 & $1.69^{\mathrm{a}}$ & 2.50 & 1.01 & 1.18 & 1.57 & 1.21 & 1.54 & $1.38^{\mathrm{a}}$ \\
\hline \multirow[t]{2}{*}{ T8 } & 0.50 & 1.11 & 0.96 & $0.86^{\mathrm{b}}$ & 1.85 & 1.23 & $1.54^{\mathrm{a}}$ & 2.17 & 1.01 & 1.20 & 1.46 & 1.14 & 1.45 & $1.30^{\mathrm{b}}$ \\
\hline & $1.11^{\mathrm{a}, \mathrm{b}}$ & $1.25^{\mathrm{a}}$ & $1.03^{b}$ & & $1.72^{\mathrm{a}}$ & $1.22^{\mathrm{b}}$ & & $1.48^{\mathrm{a}}$ & $1.13^{\mathrm{b}}$ & $1.34^{\mathrm{ab}}$ & & $1.35^{\mathrm{a}}$ & $1.54^{\mathrm{b}}$ & \\
\hline
\end{tabular}

Letter following means indicate intergroup statistical differences between ambient TA-N concentrations or period. Means not sharing a common superscript were significantly different $(P<0.05)$.

Table 5

Comparison of blood parameters in sea bass acclimated to six different ammonia concentrations for 61 days (period 1)

\begin{tabular}{|c|c|c|c|c|c|c|c|}
\hline & Control & $\mathrm{T} 1$ & $\mathrm{~T} 3$ & T5 & T6 & $\mathrm{T} 8$ & \\
\hline Osmolarity (mOsm $\left.~^{-1}\right)$ & $372.0 \pm 4.0$ & $369.6 \pm 5.1$ & $376.0 \pm 5.2$ & $366.4 \pm 5.0$ & $371.3 \pm 10.1$ & $374.1 \pm 8.0$ & NS \\
\hline $\mathrm{Cl}^{-}\left(\mathrm{mmol} \mathrm{l} \mathrm{l}^{-1}\right)$ & $159.0 \pm 2.5$ & $155.8 \pm 2.3$ & $158.0 \pm 2.2$ & $153.0 \pm 2.2$ & $155.9 \pm 2.4$ & $155.3 \pm 3.6$ & NS \\
\hline $\mathrm{Na}^{+}\left(\mathrm{mmol} \mathrm{l}^{-1}\right)$ & $206.6 \pm 2.3$ & $208.9 \pm 2.0$ & $212.7 \pm 3.4$ & $214.1 \pm 2.9$ & $214.5 \pm 4.3$ & $215.8 \pm 8.2$ & NS \\
\hline $\mathrm{K}^{+}\left(\mathrm{mmol} \mathrm{l}^{-1}\right)$ & $7.2 \pm 0.5$ & $5.7 \pm 0.1$ & $6.2 \pm 0.4$ & $6.6 \pm 0.5$ & $6.7 \pm 0.6$ & $6.4 \pm 0.5$ & NS \\
\hline TA-N $\left(\mathrm{mg} \mathrm{l}^{-1}\right)$ & $3.3 \pm 0.5^{\mathrm{a}}$ & $4.6 \pm 0.6^{\mathrm{a}}$ & $6.0 \pm 0.2^{\mathrm{a}, \mathrm{b}}$ & $8.7 \pm 0.9^{\mathrm{b}, \mathrm{c}}$ & $8.5 \pm 2.1^{\mathrm{b}, \mathrm{c}}$ & $10.9 \pm 2.3^{\mathrm{c}}$ & $P=9 \times 10^{-6}$ \\
\hline Urea-N $\left(\mathrm{mg} \mathrm{l}^{-1}\right)$ & $18.0 \pm 1.7$ & $14.5 \pm 1.2$ & $14.1 \pm 1.5$ & $14.3 \pm 0.9$ & $14.6 \pm 1.6$ & $19.1 \pm 3.6$ & NS \\
\hline Haematocrit (\%) & $27 \pm 1.5$ & $28 \pm 1.5$ & $26 \pm 1$ & $26 \pm 1$ & $25 \pm 0.5$ & $24 \pm 2$ & NS \\
\hline Glucose (mg $\left.1^{-1}\right)$ & $2.4 \pm 0.1$ & $1.8 \pm 0.2$ & $2.6 \pm 0.3$ & $2.3 \pm 0.3$ & $2.7 \pm 0.4$ & $2.7 \pm 0.4$ & NS \\
\hline $\mathrm{T}_{3}\left(\mathrm{ng} \mathrm{ml}^{-1}\right)$ & $55.9 \pm 3.6^{\mathrm{a}, \mathrm{b}}$ & $62.5 \pm 3.6^{b}$ & $61.5 \pm 5.2^{b}$ & $53.0 \pm 3.3^{\mathrm{a}, \mathrm{b}}$ & $48.2 \pm 2.9^{\mathrm{a}}$ & $46.8 \pm 3.0^{\mathrm{a}}$ & $P=0.007$ \\
\hline
\end{tabular}

The highest tri-iodo-thyronine concentrations were observed in the T1 and T3 groups and the lowest in the T6 and T8 groups, while the control group had intermediate concentrations.

\subsection{Period 2 (ambient ammonia, starved fish)}

When starved, all the fish lost weight. Individual weight loss (Table 3) was $1-5 \%$ (averaging $2.8 \%$ ) of the individual weight and was not correlated to ammonia levels. A regression using every fish weight in all the treatments gave the following equation:

$\mathrm{W}_{71}=0.975 \times \mathrm{W}_{61}-1.603 ; \quad \mathrm{r}^{2}=0.99, \mathrm{n}=360$

The same regression, but on ranks, gave the following equation:

$\mathrm{Rk}_{71}=1.002 \times \mathrm{Rk}_{61}-0.406 ; \quad \mathrm{r}^{2}=0.99, \mathrm{n}=360$

where $W_{71}\left(W_{61}\right)$ and $\mathrm{Rk}_{71}\left(\mathrm{Rk}_{61}\right)$ were the weight (the rank of the weight) of all the fish sampled in the 11 tanks at day 71 (day 61). The individual ranking was maintained irrespective of ammonia levels. The same observation was made on a comparison of ranks of average weights between treatments. Based on average weight, the groups observed on day 61 were still noticeable on day 71. Differences between negative SGR were significant, but in general were indepen- dent from individual weight and treatment. The $\mathrm{CV}$ of fish weight did not vary during this fasting period (sign-test, $n=9, P>0.05$ ).

Ammonia levels had no significant effect on urea excretion (range $20-28 \mathrm{mg} \mathrm{kg}^{-1} \mathrm{BW} \mathrm{d}^{-1}$ ) during the starvation period, although a tendency to increased excretion was noticed. Oxygen uptake (range $142-173 \mathrm{mg} \mathrm{kg}^{-1} \mathrm{BW} \mathrm{h}^{-1}$ ) in fasting fish was independent from ammonia level $(n=24$, $\left.r^{2}=0.17\right)$.

\subsection{Period 3 (no ammonia, fed fish)}

Growth data are summarised in Fig. 1 and Table 2. From day 71 to 114 , the significance of the Fisher test applied to weight decreased from 11.3 to 3.8 , indicating a drop in the intergroup variance, in contrast to what had been observed during the first period. These three groups progressively disappeared and were no longer observed at day 114. At the end of period 3, only tanks T2 (the lowest) and T3 (the highest) were significantly different from the others. The ratio between the highest and the lowest average weight decreased from 1.33 at day 71 to 1.19 at day 93, and then stabilised. At the same time, an analysis of rank between day 71 and 114 indicated that ranks were less conserved $\left(r^{2}=0.73\right)$, in contrast to what was observed during the fasting period. From day 71 to 93 , best weight gains were 
observed in fish, which had been exposed to high ammonia levels. During the day 93-114 phase, intertreatment variance decreased dramatically; fish which had been exposed to the lowest ammonia levels had the lowest SGR, and only two groups were then observed. These variations were not dependant on individual weight at days 71 and 93 since introducing them as a co-variable did not modify the significance of the ANOVA. The CV of fish weight between treatments did not change with time (sign-test, $n=9, P>0.05$ ). For period 3, based on the SGR, the three same groups observed during period 1 were found: below 4.90, above $10.79 \mathrm{mg} \mathrm{l}^{-1}$ TA-N, and the intermediate group. The determination coefficients of the regression between SGR and VFI were 0.90 and 0.70 during the day 71-93 and 93-114 phases, respectively.

During period 3, the initial feeding activity was very high, except in the Control and T1 conditions, and then decreased during three consecutive weeks before stabilising (Fig. 4). Overall the VFI decreased significantly from the day 7193 to 93-114 phase (Table 4). Two groups, below and above $4.90 \mathrm{mg} \mathrm{l}^{-1}$, were recorded. A LR between VFI and initial TA-N levels indicated that VFI increased with TA-N during the day 71-93 and 93-114 phases $\left(r^{2}=0.70\right.$ and 0.69 , respectively). A very high correlation was found between SGR and VFI during this recovery process $\left(r^{2}=0.95, P=2 \times\right.$ $\left.10^{-11}\right)$.

FCR increased from the day 71-93 to 93-114 phase. FCR appeared to decrease as the initial ammonia levels increased, even if only those fish previously exposed to $16.11 \mathrm{mg} \mathrm{l}^{-1}$ TA-N appeared to be significantly different from the others (Table 4). From day 1 to 114 , the correlation between FCR and ammonia levels (Fig. 5) was as follows:

$\mathrm{FCR}=-10.1 \times 10^{-3} \mathrm{TA}-\mathrm{N}+1.38 ; \quad \mathrm{r}^{2}=0.55, \mathrm{n}=9$

The linear relationship did not strongly describe the link between FCR and TA-N levels, but the slope was statistically different from zero $(P=0.011)$, indicating that they were not independent.

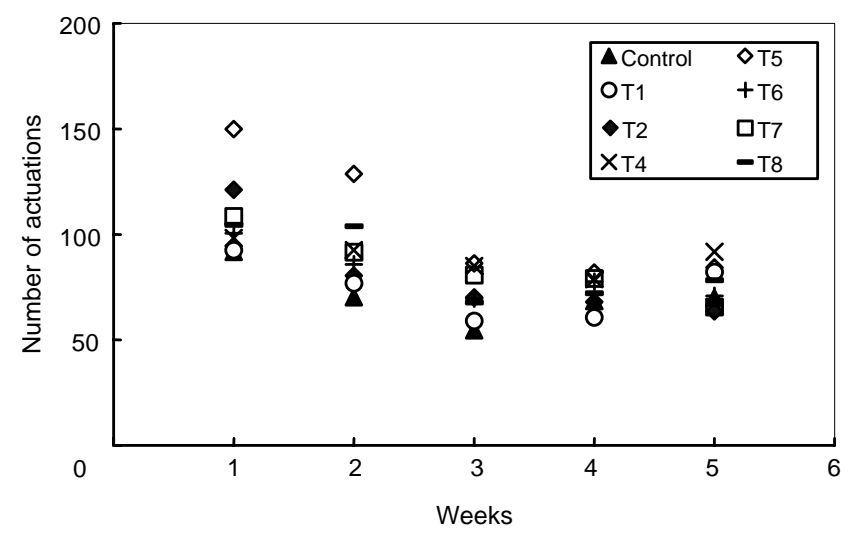

Fig. 4. Average weekly number of actuations during period 3 for eight experimental conditions tested.

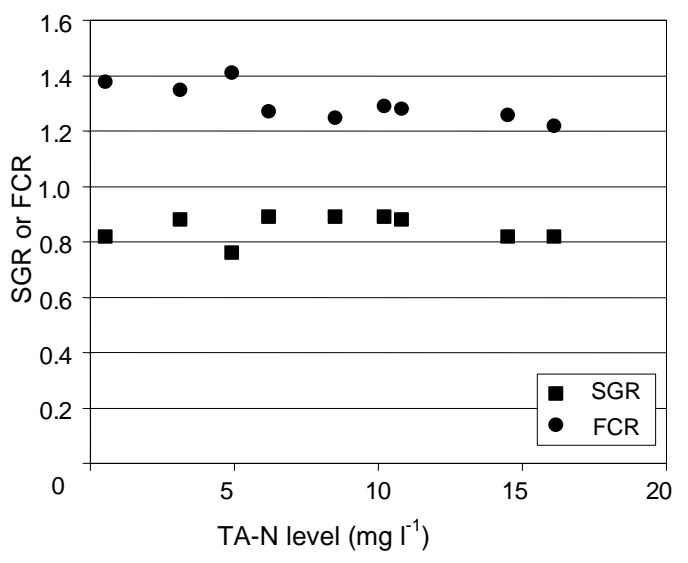

Fig. 5. Average SGR (\% per day) and apparent FCR from day 1 to 114 (periods 1,2 and 3) vs. the ambient.

Over the whole period of the experiment, i.e. from day 1 to 114, a LR between SGR and initial TA-N ammonia levels gave the following result (Fig. 5):

$\mathrm{SRG}=0.845+3.9 \times 10^{-4} \mathrm{TA}-\mathrm{Nr}^{2}=3.9 \times 10^{-4}, \mathrm{n}=9$

where TA-N is the ammonia concentration in the tank (in $\mathrm{mg} \mathrm{l}^{-1}$ TA-N). Generally, SGR was, therefore, independent from the initial ambient TA-N levels.

\section{Discussion}

\subsection{Effect of ammonia on un-acclimated fish (period 1, day 0-19)}

After external observation of darkening and hyperventilation, the reduction in VFI of sea bass was the first observed effect of a sharp increase in ammonia levels in the water. This observation is consistent with behavioural changes in many fish species (Wajsbrot et al., 1993 in sea bream; Rasmussen and Korsgaard, 1996; Person-Le Ruyet et al., 1997a in turbot; Lemarié et al., in press in sea bass). The magnitude and duration of the decreases in VFI (Table 4) that occurred during the initial 19 days at the three highest ambient ammonia concentrations were dependent on ammonia levels. Although the reasons for such a short term feeding and/or metabolic adaptation observed in many fish species in response to any environmental stressor remains unclear, two explanations can be put forward: functional alterations of the central nervous system (Daoust and Ferguson, 1984; Hermenegildo et al., 2000; Montfort et al., 2000) and lowering of oxygen availability to fish tissues despite the fact that there is no restriction of oxygen in water (Sousa and Meade, 1977). Both are likely to have an influence, but neurological disturbances are mostly reported to occur at high ammonia concentrations in plasma and other tissues (Mommsen and Walsh, 1992; Hermenegildo et al., 2000). Fish exposed to the three highest ammonia concentrations tested, which were voluntarily starving, quickly recovered an appetite similar to fish in T4 and T5 conditions, (the actual VFIs during their feeding 
phase were, respectively, $1.19,0.99$ and 1.05 under the 10.79 , 14.45 and $16.11 \mathrm{mg} \mathrm{l}^{-1}$ TA-N conditions), indicating that the acclimation process was rapid. It appeared that low ammonia concentrations acted on the satiation mechanisms of unacclimated fish before the neurobiological effects of higher concentrations led to the absence of any feeding activity.

As previously reported (Boujard et al., 1996; Azzaydi et al., 1998), sea bass feeding activity is nocturnal under winter environmental conditions, and diurnal during the rest of the year. In our experiment, the environmental conditions used $\left(22^{\circ} \mathrm{C}, 16 \mathrm{~L} / 8 \mathrm{D}\right)$ were comparable to summer conditions, and feeding rhythms were strictly diurnal. Aranda et al. (1999) suggested an endogenous circannual control that could be influenced by other factors than temperature and photoperiod. When reported, the shift from diurnal to nocturnal feeding activity occurred suddenly (Sanchez-Vasquez et al., 1995). In this study, circadian rhythms of feeding activity were not modified by the initial sharp increase in ambient ammonia or by cutting off the ammonia supply (period 3). Similarly, Azzaydi et al. (1998) reported that temperature and photoperiod did not account for the day-to-day variations observed in feeding rhythms, which were presumably controlled by internal factors such as appetite or social interactions. They confirmed the great flexibility in daily feeding rhythms of sea bass (Boujard et al., 1996; Azzaydi et al., 1998). The regulation of feed intake was controlled by a satiation mechanism, but feeding activity was driven by an endogenous clock (Boujard et al., 2000). During the day 1-19 phase, the lower peak of ingestion recorded during the first hour of day light was the main cause of the overall decrease in VFI.

This VFI perturbations affected growth. The reduction in growth initially observed from day 1 to 19 accounted for $51-400 \%$ of the overall loss of growth over the whole period (day 1-61). A major impact of ammonia on growth rate can be attributed to feeding disturbances during the initial days of exposure. This is confirmed by the observations made by Person-Le Ruyet et al. (1998) on sea bream and turbot describing the very rapid increase of plasma TA-N (in less than an hour) and the external regulation which followed within 4 days in fish exposed to ambient ammonia. The absence of any major change in the $\mathrm{CV}$ of the weight indicated that fish responded in the same way as has been described in feed restricted fish (Saether and Jobling, 1999). This has been associated with a lack of dominance-subordination relationships (Jobling et al., 1999).

Decreases in VFI at the highest ammonia concentrations tested, accounted for $90 \%$ of the reduction in SGR observed at the onset of ammonia exposure (day 1-19). Concomitantly, apparent FCR increased at the two highest ammonia concentrations, as was observed in turbot when feeding was significantly decreased due to ammonia (Rasmussen and Korsgaard, 1996; Person-Le Ruyet et al., 1997b). Nevertheless, if we include an initial loss of weight due to voluntary starvation similar to the one recorded during the second period, the recalculated FCRs were 1.36 and 1.19 in tanks T7 and T8. They were then comparable to other conditions. The maintenance requirement for $140 \mathrm{~g}$ sea bass at $23{ }^{\circ} \mathrm{C}$ has been evaluated at $56 \mathrm{~kJ} \mathrm{~kg}^{-1} \mathrm{~d}^{-1}$ (Lupatcsh et al., 2003). Starving fish in these two conditions appeared to ingest $94.5 \mathrm{~kJ} \mathrm{~kg}^{-1}$ $\mathrm{d}^{-1}$. The available energy for growth $\left(39 \mathrm{~kJ} \mathrm{~kg}^{-1} \mathrm{~d}^{-1}\right)$ in those situations would promote a relative smaller growth and food efficiency compared with control. In that sense, the FCR increase at high ambient TA-N levels could mostly be attributed to a reduction of ingestion.

\subsection{Effect of ammonia on acclimated fish (period 1, day 19-61 and period 2)}

Beyond the day 0-19 acclimation period, VFI was independent from ambient ammonia concentration (Table 4). The decrease with time observed at the lowest ammonia concentrations was related to fish growth, while the relative increase observed on day 19-41 at the highest ammonia levels was due to a progressive acclimation of the fish to ammonia. Feeding activity, estimated as the number of times the feeding mechanism was actuated, increased slowly after voluntary starvation, suggesting that increases in VFI were not due to a rapid compensatory mechanism following partial starvation. Very few studies have included a sufficiently long time course of ammonia exposure to describe this feeding recovery phase. In hand-fed juvenile turbot exposed to an ammonia concentration of $10 \mathrm{mg}^{-1} \mathrm{TA}-\mathrm{N}$, a 7-day period (acclimation) was required to recover the initial standard feeding level, and a 13-day period for partial reversion of physiological disturbances (Person-Le Ruyet et al., 1995, 1997a). Based on the findings of this study, sea bass respond in the same way as other marine species with regards to feed requirements under ammonia stress.

From day 19, in all ammonia-exposed groups, SGR was independent from ammonia level and was similar to the control (Table 2). There was a strong link between VFI and growth, as has already been reported in turbot (Rasmussen and Korsgaard, 1996; Person-Le Ruyet et al., 1997a, b) and the capacity of fish to recover from a transient decrease in feeding and growth caused by ammonia exposure was confirmed. Nevertheless, in no case could fish compensate for the initial losses in growth, and the final weight (day 61) of fish exposed to more than $14.45 \mathrm{mg} \mathrm{l}^{-1}$ TA-N remained significantly lower than in other groups, as was previously observed in $12 \mathrm{~g}$ sea bass (Lemarié et al., in press). Sea bass juveniles of $140 \mathrm{~g}$ (this study) or $12 \mathrm{~g}$ (Lemarié et al., in press) were rapidly able to feed and grow under $16 \mathrm{mg}^{-1}$ TA-N. The no-growth ammonia concentration could not be estimated in this study. In 50-70 g turbot, the concentration of $36 \mathrm{mg}^{-1}$ TA-N $\left(0.73 \mathrm{mg} \mathrm{l}^{-1}\right.$ UIA-N) was reported to stop any growth (Person-Le Ruyet et al., 1998). In $12 \mathrm{~g}$ sea bass, the 55-day $\mathrm{EC}_{50}$ (concentration at which growth is reduced by $50 \%$ ) was $22 \mathrm{mg} \mathrm{l}^{-1}$ TA-N compared with 17-21 for turbot. It can be expected that in $140 \mathrm{~g}$ sea bass, sensitivity to ammonia be of the same order of magnitude.

Beyond the acclimation period, for unexplained reasons, apparent FCR improved in all experimental conditions; the 
higher the level of ammonia, the greater the improvement in FCR. In acclimated fish, the best FCR values were obtained for the two highest ammonia concentrations, suggesting that in general the efficiency in food and energy processing by the fish had not been altered, and that compensation could have occurred in the form of a greater metabolic efficiency rather than growth rate.

ADCs of protein were not modified by 61 days of exposure to a maximum of $16 \mathrm{mg}^{-1}$ TA-N. Thus the efficiency of digestion was not modified, in contradiction with the results of Rasmussen and Korsgaard (1996) on juvenile turbot. However, their investigations lasted 20 days only, and possibly the fish were not totally acclimated. The PPV and the lipid content, as measured for the first period, were not modified by ammonia levels. The major metabolic functions were not affected, and energy expenditure did not modify the relative allocation of energy by the fish. Exploring DNA and RNA levels in turbot liver, Rasmussen and Korsgaard (1996) found no evidence of modification in liver RNA levels, which is the first step in protein synthesis, and no change in body water content versus ammonia concentrations. Person-Le Ruyet et al. (1997b, 1998) reported changes in fat and water content versus ammonia concentrations in 14 and $53 \mathrm{~g}$ turbot only when growth was markedly reduced (i.e. over $11 \mathrm{mg}^{-1}$ TA-N). In sea bass a similar decrease in fat content was described by Pastoureaud (1991) when the feeding level was reduced under the effect of low temperature. In this study, metabolic pathways were not apparently affected at the ammonia concentrations tested, and were qualitatively maintained.

This was confirmed by the marginal effect of ammonia on three physiological parameters in period 2: oxygen consumption, urea excretion and plasma glucose. Oxygen consumption in starved fish was independent from ambient ammonia, showing that acclimated fish did not use additional energy to counter-balance the internal ammonia level. Oxygen consumption increases have mostly been reported to be shortterm adjustments linked to increased ventilation frequency (Sousa and Meade, 1977). Endogenous urea excretion was not significantly affected by ammonia in the range of concentrations tested. Guérin-Ancey (1976) observed that the increase in urea excretion was not significant in big fish (2- and 3 -year-old) while it was significant in 1-year-old fish. Only young fish exposed to high ammonia levels appeared to utilise urea production to detoxify ammonia (Guérin-Ancey, 1976; Walsh et al., 1990; Mommsen and Walsh, 1992; Person-Le Ruyet et al., 1997a). Plasma glucose was also independent from ammonia concentrations. Ammonia is reported to increase glycolysis rate (Sousa and Meade, 1977; Fivelstad et al., 1995) at high levels (more than $20 \mathrm{mg} \mathrm{l}^{-1}$ TA-N). This mechanism was probably not induced at the ammonia concentrations tested in this study, or was active only during the first days of exposure. The significantly lower plasma tri-iodo-thyronine concentration at the highest ammonia concentrations tested may represent an interesting indicator of notable disturbances in sea bass. In turbot, a low plasma tri-iodo-thyronine concentration is indicative of a decrease in growth potential (Bœuf et al., 1999). In acclimated fish, apart from a dose-dependant ammonia accumulation in blood plasma, no major physiological disturbances were observed. The relationship between plasma TA-N and ambient ammonia was in agreement with previous results recorded in sea bass (Lemarié et al., in press) and in other freshwater and marine species (Arillo et al., 1981; Knoph and Thorud, 1996; Person-Le Ruyet et al., 1995, 1998).

Starving the fish during their exposure to ammonia (period 2) failed to reveal any effect of ammonia. This is consistent with an adaptation of the fish as measured by their endogenous metabolic activity.

The present study showed that in 130-140 g (initial weight) sea bass exposed to stabilised ammonia concentrations for 61-71 days, the non-observable effect concentration (NOEC) was approximately $6 \mathrm{mg}^{-1}$ TA-N and due to intra group variability, the lowest observable effect concentration (LOEC) was $8.5 \mathrm{mg}^{-1}$ TA-N. In smaller sea bass (12 g) LOEC was $8.5 \mathrm{mg} \mathrm{l}^{-1}$ and NOEC $6 \mathrm{mg} \mathrm{l}^{-1}$ (Lemarié et al., in press). It cannot be concluded that the ammonia sensibility in juvenile and immature fish was different, since the experimental conditions were different.

\subsection{Return to ammonia-free conditions (period 3)}

The usual observations made when feeding fish after a period of starvation or feed restriction were observed during the third period: hyperphagy (Saether and Jobling, 1999; Xie et al., 2001), compensatory growth (Weatherley and Gill, 1981; Dobson and Holmes, 1984; Pastoureaud, 1991), absence of increase in the CV of weight (Jobling and Koskela, 1996; Jobling et al., 1999), and improved feed efficiency (Boujard et al., 2000). Our study is original in the sense that feed restriction was a consequence of an external pollutant and that the fish were free to regulate their feeding level.

The higher the initial feed restriction, the greater the growth compensation. This recurring observation seems to be independent from the cause: temperature (Pastoureaud, 1991; Nicieza and Metcalfe, 1997), partial feed restriction (Jobling and Koskela, 1996; Nicieza and Metcalfe, 1997; Saether and Jobling, 1999), full starvation (Rueda et al., 1998; Boujard et al., 2000; Wang et al., 2000) or pollutants (Jobling, 1994). The duration and intensity of food deprivation have an effect on the subsequent compensation. Wang et al. (2000) reported that feed intake and SGR in hybrid tilapia were higher when the duration of starvation was increased. In that study, fish submitted to the longest starvation periods still had lower body weights at the end of a compensation period of 4 or 6 weeks. In our case, the cumulative effects of food deprivation, starvation and ammonia toxicity over 71 days were not sufficient to prevent fish from fully compensating their growth deficit. That is not to say that a longer exposure time and/or ammonia level would have induced the same consequences.

VFI accounted for $95 \%$ of the SGR during the third period and was dependent on the level of ammonia at the beginning 
of the phase. This dependence was higher during the day 71-93 phase than during the 93-114 phase, indicating that the phenomenon of hyperphagia was limited with time. Nicieza and Metcalfe (1997) reported that the timing and duration of increased food intake rates were dependent upon the physiological status of the fish (in their case premigratory and non-migratory Atlantic salmon) and to the past nutritional history of the fish (Boujard et al., 2000). Increased feeding levels have been attributed to the increase of the duration of the daily feeding period (Nicieza and Metcalfe, 1997). In our case, hyperphagia was correlated to an increased number of actuations during the same daily feeding period. Major hyperphagia was recorded during the first 2 weeks after returning to ammonia-free conditions, indicating a very quick return to normal ingestion rates. This is in accordance with a very rapid decrease (in a few minutes) of plasma ammonia to reference levels after returning to ammonia-free water (Wise et al., 1989; Person-Le Ruyet et al., 1998).

Feed energy and protein content did not seem to have an effect on compensatory growth in channel catfish (Gaylord and Gatlin, 2001). Qian et al. (2000) demonstrated in gibel carp (Carassius auratus gibelio) that digestibility of protein was not modified during compensatory growth. Therefore, fish mainly compensated through a higher consumption of dietary energy. Regulation of appetite during compensatory growth appeared to be under the control of plasma free fatty acid and glucose concentrations in rainbow trout (Boujard et al., 2000).

The improvement in FCR ratios observed under the effect of ammonia during the third period varied in the same way as the VFI during the first period. The lower the VFI, the lower the FCR. Such improvement in food efficiency during growth compensation has been observed by several authors (Dobson and Holmes, 1984; Qian et al., 2000; Quinton and Blake, 1990; Boujard et al., 2000) but not by Jobling and Koskela (1996). Boujard et al. (2000) suggested that moderate food deprivation and starvation had a different effect on food conversion efficiency in rainbow trout. In our experiments, all the fish were submitted to the same duration of starvation, and still FCR were different between the ambient TA-N concentrations. FCR improvement could, therefore, be attributed to initial VFI levels. The present study did not demonstrate any changes in basal metabolism as measured by oxygen consumption in fasting fish, and could not support the theory of Russel and Wootton (1992) that FCR improvement could be caused by a decrease of basal metabolism during the feed deprivation period and that it extends to the initial stages of re-alimentation. The underlying mechanism is worth investigating.

In conclusion, our study shows that in the range and over the duration of exposure to ammonia tested, sea bass were able to adapt to their environment after a period of about 3 weeks. After 60 days, the major physiological disturbances observed were accumulation of plasma ammonia (indicating ammonia excretion problems) and a T3 decrease. Growth and nutritional parameters were restorable during the exposure, despite a significant effect on growth when the level of ammonia was above $5 \mathrm{mg} \mathrm{l}^{-1}$ TA-N.

A compensation comparable with what has been observed in fasting fish occurred when returning to ammonia-free conditions. The metabolic and physiological functions of the fish were not affected after a 71-day exposure, and surprisingly the ammonia-free condition did not provide the best results. Nevertheless, long-term effects from much longer exposure to ambient ammonia have still to be investigated, with special attention to interactions with other ecological factors (e.g. $\mathrm{pH}$ and $\mathrm{CO}_{2}$ ). Therefore, caution should be exercised before extrapolating laboratory results to farm level conditions.

\section{Acknowledgements}

The authors would like to thank J. Mélard and J.P. Blancheton for their assistance.

\section{References}

Aminot, A., Kérouel, R., 1982. Dosage automatique de l'urée dans l'eau de mer: une méthode très sensible à la diacétyl-monoxime. Can. J. Fish. Aquat. Sci. 39, 174-183.

Aranda, A., Sanchez-Vasquez, F.J., Madrid, J.A., 1999. Influence of water temperature on demand-feeding rhythms in sea bass. J. Fish Biol. 55, 1029-1039.

Arillo, A., Margiocco, C., Melodia, F., Mesi, P., 1981. Effects of ammonia on liver lysosomal functionality in Salmo gairdneri Rich. J. Exp. Zool. 218, 321-326.

Azzaydi, M., Madrid, J.A., Zamora, S., Sanchez-Vasquez, F.J., Martinez, F.J., 1998. Effect of three feeding strategies (automatic, ad libitum demand feeding, and time restricted demand-feeding) on feeding rhythms and growth in European sea bass (Dicentrarchus labrax L.). Aquaculture 163, 285-296.

Bœuf, G., Le Bail, P.Y., Prunet, P., 1989. Growth hormones and thyroid hormones during Atlantic salmon, Salmo salar L., smolting and after transfer to seawater. Aquaculture 82, 257-268.

Bœuf, G., Martin, P., Sévère, A., Person-Le Ruyet, J., Pichavant, K., Burel, C., Le Roux, A., Cauty, C., Marchelidon, J., Le Bail, P.Y., Smal, J., 1999. Somatotropin, thyroid hormones and growth in turbot (Psetta maxima): effects of temperature, hypoxia and ammonia. In: Roubos, E.W., Wendelaar Bonga, S.E., Vaudry, H., De Loof, A. (Eds.), Recent Developments in Comparative Endocrinology and Neurobiology. Shaker Publisher, Maastricht, Netherlands, pp. 163-165.

Bolin, D.W., King, R.P., Klostermann, W.W., 1952. A simplified method for the determination of chromic oxide $\left(\mathrm{Cr}_{2} \mathrm{O}_{3}\right)$ when used as an inert substance. Science 16, 634-635.

Boujard, T., Dugy, X., Genner, D., Gosset, C., Grig, C., 1992. Description of a modular, low cost, eater meter for the study of feeding behaviour and food preferences in fish. Physiol. Behav. 52, 1101-1106.

Boujard, T., Jourdan, M., Kentouri, M., Divanach, P., 1996. Diel feeding activity and the effect of time-restricted self-feeding on growth and feed conversion in European sea bass. Aquaculture 127, 129-137.

Boujard, T., Gélineau, A., Corraze, G., Kaushik, S., Gasset, E., Covès, D., Dutto, G., 2000. Effect of dietary lipid content on circadian rhythm of feeding activity in European sea bass. Physiol. Behav. 68, 683-689.

Bower, C.E., Holm-Hansen, T., 1980. A salicylate-hypochlorite method for determining ammonia in seawater. Can. J. Fish. Aquat. Sci. 37, 794-798. 
Daoust, P.Y., Ferguson, H.W., 1984. The pathology of chronic ammonia toxicity in rainbow trout, Salmo gairdneri Richardson. J. Fish Dis. 7, 199-205.

Dobson, S.H., Holmes, R.M., 1984. Compensatory growth in the rainbow trout, Salmo gairdneri Richardson. J. Fish Biol. 25, 649-656.

Dosdat, A., Gaumet, F., Chartois, H., 1994. Marine aquaculture effluent monitoring: methodological approach to the evaluation of nitrogen and phosphorus excretion by fish. Aquacult. Eng. 14, 59-84.

Dosdat, A., Servais, F., Métailler, R., Huelvan, C., Desbruyères, E., 1996. Comparison of nitrogenous losses in five teleost fish species. Aquaculture 141, 107-127.

Fivelstad, S., Schwarz, J., Stromsnes, H., 1995. Sublethal effects and safe levels of ammonia in seawater for Atlantic salmon postmolts (Salmo salar L.). Aquacult. Eng. 14, 271-280.

Forster, R.P., Goldstein, L., 1969. Formation of excretory products. In: Hoar, W.S., Randall, D.J. (Eds.), Fish Physiology, vol. 1. Academic Press, New York, pp. 313-350.

Guérin-Ancey, O., 1976. Etude expérimentale de l'excrétion azotée du bar (Dicentrarchus labrax) en cours de croissance. III Effets du volume et de la concentration initiale en ammoniac sur l'excrétion d'ammoniac et d'urée. Aquaculture 9, 253-258.

Gaylord, T.G., Gatlin III, D.M., 2001. Dietary protein and energy modifications to maximize compensatory growth of channel catfish (Ictalurus punctatus). Aquaculture 194, 337-348.

Handy, R.D., Poxton, M.G., 1993. Nitrogen pollution in mariculture: toxicity and excretion of nitrogenous compounds by marine fish. Rev. Fish Biol. Fish. 3, 205-241.

Hermenegildo, C., Montfort, P., Felipo, V., 2000. Activation of $N$-methyl-Daspartate receptors in rat brain in vivo following acute ammonia intoxication: characterization by in vivo brain microdialysis. Hepatology 31, 709-715.

Jobling, M., 1994. Ingestion, absorption and digestion. In: Jobling, M. (Ed.), Fish Bioenergetics. Chapman and Hall, London, pp. 99-119.

Jobling, M., Koskela, J., 1996. Interindividual variations in feeding and growth in rainbow trout during restricted feeding and in a subsequent period of compensatory growth. J. Fish Biol. 49, 658-667.

Jobling, M., Koskela, J., Winberg, S., 1999. Feeding and growth of white fish fed restricted and abundant rations: influences on growth heterogeneity and brain serotonergic activity. J. Fish Biol. 54, 437-449.

Johansson, O., Wedborg, M., 1980. The ammonia-ammonium equilibrium in seawater at temperatures between 5 and $25^{\circ} \mathrm{C}$. J. Solut. Chem. 91 , 37-44.

Knoph, M., Thorud, K., 1996. Toxicity of ammonia to Atlantic salmon (Salmo salar L.) in seawater. Effects on plasma osmolarity, ion, ammonia, urea and glucose levels and heamatologic parameters. Comp. Biochem. Physiol. 113, 375-381.

Lemarié, G., Dosdat, A., Covès, D., Dutto, G., Gasset, E., Person-Le Ruyet, J., 2003. Effect of chromic ammonia exposure on growth of European sea bass (Dicentrarchus labrax) juveniles. Aquaculture (in press).

Lupatcsh, I., Kissil, G.W., Sklan, D., 2003. Comparison of energy and protein efficiency among three fish Speciues gilthead sea bream (Sparus aurata), European sea bass (Dicentrarchus labrax) and white grouper (Epiniphelus aureus): energy expenditure for protein and lipid deposition. Aquaculture 225, 175-189.

Mommsen, T.P., Walsh, P.J., 1992. Biochemical and environmental perspectives on nitrogen metabolism of fishes. Experientia 48, 583-593.

Montfort, P., Montoliu, C., Hermenegildo, C., Munoz, M.D., Felipo, V., 2000. Differential effects of acute and chronic hyperammoniemia on signal transduction pathways associated to NMDA receptors. Neurochem. Int. 37, 249-253.

Nicieza, A.G., Metcalfe, N.B., 1997. Growth compensation in juvenile Atlantic salmon: responses to depressed temperature and food availability. Ecology 78, 2385-2400.
Pastoureaud, A., 1991. Influence of starvation at low temperature on utilization of energy reserves, appetite recovery and growth character in sea bass, Dicentrarchus labrax. Aquaculture 99, 167-178.

Person-Le Ruyet, J., Chartois, H., Quemener, L., 1995. Comparative acute ammonia toxicity in marine fish and plasma ammonia response. Aquaculture 136, 181-194.

Person-Le Ruyet, J., Galland, R., Le Roux, A., Chartois, H., 1997. Chronic ammonia toxicity in juvenile turbot (Scophthalmus maximus). Aquaculture $154,155-171$.

Person-Le Ruyet, J., Delbard, C., Chartois, H., Le Delliou, H., 1997. Toxicity of ammonia to turbot juveniles: 1-Effects on survival, growth and food utilisation. Aquat. Living Resour. 10, 307-314.

Person-Le Ruyet, J., Bœuf, G., Zambonino-Infante, J., Helgason, S., Le Roux, A., 1998. Short-term physiological changes in turbot and seabream juveniles exposed to exogenous ammonia. Comp. Biochem. Physiol. 3, 511-517.

Qian, X., Cui, Y., Xiong, B., Yang, Y., 2000. Compensatory growth, feed utilization and activity in gibel carp, following food deprivation. J. Fish Biol. 56, 228-232.

Quinton, J.C., Blake, R.W., 1990. The effect of feed cycling and ration level on the compensatory growth response in rainbow trout. Oncorhynchus mykiss. J. Fish Biol. 37, 33-41.

Rasmussen, R.S., Korsgaard, B., 1996. The effect of external ammonia on growth and food utilization of juvenile turbot (Scophthalmus maximus L.). J. Exp. Mar. Biol. Ecol. 205, 35-48.

Rueda, F.M., Martinez, F.J., Zamora, S., Kentouri, M., Divanach, P., 1998. Effect of fasting and refeeding on growth and body composition of red porgy, Pagrus pagrus L. Aquacult. Res. 29, 447-452.

Russel, N.R., Wootton, R.J., 1992. Appetite and growth compensation in the European minnow, Phoxinus phoxinus (Cyprinidae), following short period of food restriction. Environ. Biol. Fish. 34, 277-285.

Russo, R.C., Thurston, R.V., 1991. Toxicity of ammonia, nitrite and nitrate to fishes. In: Brune, E., Tomasso, J.R. (Eds.), Aquaculture and Water Quality. World Aquacultural Society Publication, pp. 58-89.

Saether, B.S., Jobling, M., 1999. The effects of ration level on feed intake and growth, and compensatory growth after restricted feeding, in turbot Scophthalmus maximus L. Aquacult. Res. 30, 647-653.

Sanchez-Vasquez, F.J., Madrid, J.A., Zamora, S., 1995. Circadian rhythms of feeding activity in sea bass (Dicentrarchus labrax, L.): dual phasing capacity of diel demand-feeding pattern. Chronobiol. Int. 15, 256-266.

Sousa, R.J., Meade, T., 1977. The influence of ammonia on the oxygen delivery system of coho salmon haemoglobin. Comp. Biochem. Physiol. 58A, 23-28.

Tomasso, J.R., 1994. Toxicity of nitrogenous wastes to aquaculture animals. Rev. Fish. Sci. 2, 291-314.

US EPA (United States Environmental Protection Agency), 1998. Update of Ambient Water Quality Criteria for Ammonia EPA 822-R-98-008. Washington, DC.

Wajsbrot, N., Gasith, A., Diamant, A., Popper, D.M., 1993. Chronic toxicity of ammonia to juvenile gilthead seabream Sparus aurata and related histopathological effects. J. Fish Biol. 43, 321-328.

Walsh, P.J., Danulat, E., Mommsen, T.P., 1990. Variation in urea excretion in the gulf toadfish Opsanus beta. Mar. Biol. 106, 323-328.

Wang, Y., Cui, Y., Yang, Y., Cai, F., 2000. Compensatory growth in hybrid tilapia Oreochromus mossambicus $\times$ O. niloticus, reared in seawater. Aquaculture 189, 101-108.

Weatherley, A.H., Gill, H.S., 1981. Recovery growth following periods of restricted rations and starvation in rainbow trout Salmo gairdneri Richardson. J. Fish Biol. 18, 195-208.

Wise, D.J., Weirich, C.R., Tomasso, J.R., 1989. Toxicity of ammonia to red drum Scianops ocellatus fingerlings with information on uptake and depuration. J. World Aquacult. Soc. 20, 188-192.

Xie, S., Zhu, X., Cui, Y., Wotton, R.J., Lei, W., Yang, Y., 2001. Compensatory growth in the gibel carp following feed deprivation: temporal patterns in growth, nutrient deposition, feed intake and body composition. J. Fish Biol. 58, 999-1009. 